The International Archives of the Photogrammetry, Remote Sensing and Spatial Information Sciences, Volume XL-4/W3, 2013 ISPRS/IGU/ICA Joint Workshop on Borderlands Modelling and Understanding for Global Sustainability 2013,

5 - 6 December 2013, Beijing, China

\title{
BORDERLANDS MODELLING AND UNDERSTANDING WITH GISS: CHALLENGES AND RESEARCH AGENDA
}

\author{
J. Chen ${ }^{\text {a, b, * }, ~ Y-J ~ G e ~}{ }^{\text {b }}$ Y. Cheng ${ }^{\text {b }}$, R. Li ${ }^{\mathrm{a}}$, Y. Cao ${ }^{\mathrm{b}}$
}

\author{
${ }^{a}$ National Geomatics Center of China, Beijing 100830, China - (chenjun, liran) @nsdi.gov.cn \\ bBeijing Normal University, Beijing100875, China - (geyj, chengyang) @bnu.edu.cn, rarerabbit@163.com
}

KEY WORDS: Borderlands, sustainable development, integrated data modelling, comprehensive analysis, geospatial information science

\begin{abstract}
:
Borderland regions are special areas and deserve more attention in global sustainable development. Reliable information and effective analysis tools are requested to support borderlands studies through the integrated utilization of geospatial analysis, web service, as well as the other domain-specific expertise. This paper has reviewed the state-of-the-art of borderlands modelling and understanding. From the perspective of geospatial information sciences (GIS), integrated data modelling, comprehensive analysis and collaborative information service are identified as the three major challenges in this filed. A research agenda is further proposed with four topics, i.e., classification and representation of borderland information, derivation of neighborhood information, development of synergetic analysis, and design and development of a geo-portal for borderlands studies. This interdisciplinary study requires a closer and in-depth collaboration of geopolitics, international relation, geography and geo-spatial information sciences.
\end{abstract}

\section{INTRODUCTION}

On the 22 June, 2012, world leaders had renewed their commitment on sustainable development and reaffirmed the promotion of an economically, socially and environmentally sustainable future of our earth for present and future generation [Hecht, et.al., 2012; www.un.org/]. A set of Sustainable Development Goals (SDGs) was agreed, such as poverty eradication, changing unsustainable and promoting sustainable patterns of consumption and production, protecting and managing the natural resource base of economic and social development, and an official United Nation (UN) paper entitled 'The future we want' was issued [UN, 2012]. At present the preparation of a post-2015 development agenda is in progress for the operational implementation of the SDGs. This has stimulated an intensive discussion and research in all its three economic, environmental and social dimensions, such as green growth [Bartelmus, 2013], Biodiversity [Pereira, et.al., 2013], global understanding [www.IGU.com]. A number of initiatives has been proposed by various organizations and societies, such as the Future Earth Initiative by International Council of Science (ICSU) [www.icsu.com], United Nations Initiative on Global Geospatial Information Management [UNITED
NATIONS E/C.20/2013/6/Add.1],

From global point of view, border regions are special areas with specific sustainable development requirement and deserve more attention. A borderland region refers in general to the land space adjoining and outside state boundary lines, or the ocean area among maritime neighbors [Anderson, 1996; Brunet-Jailly, 2011]. On one side, it is the natural transition and convergence area where people, goods, services and ideas flow across boundaries or sea from state to state [Brunet-Jailly, 2005]. The borderland cooperation has increased dramatically in the past ten years in many fields, such as cross-border infrastructure development, trans-boundary water management, and agricultural development [Bernal and Sols, 2000; Akihiro, 2008]. On the other side, border regions may have different characteristics or geographic conditions than the inner or central parts of the neighboring nations. Less attention and investments were devoted to some remote border regions. This has led to some special problems occurring in the border regions, such as cross-border pollution, conflicts in un-delimitated boundary areas, non-traditional security issues, as well as under-development in some areas. Mutual cooperation and collective problem solving in border regions will reinforce the UN SDGs and should be put into the 
The International Archives of the Photogrammetry, Remote Sensing and Spatial Information Sciences, Volume XL-4/W3, 2013 ISPRS/IGU/ICA Joint Workshop on Borderlands Modelling and Understanding for Global Sustainability 2013,

\section{5-6 December 2013, Beijing, China}

post-2015 UN sustainable development agenda.

A good understanding of the nature of border regions is fundamental for well-coordinated cooperation. This will depend critically on the availability of reliable information and the capacity of analysis and forecasting, as recognized by the UN paper 'The future we want'. During the last twenty years, earth observation and geospatial information sciences (GIS) as well as enabling platforms have enhanced our capability to analyze, monitor and report on sustainable development and other key concerns [UN-GGIM, 2012]. Having an efficient integration and effective analysis of all the socio-economic and environmental information of a given border region will help to achieve a better understanding of its historical context, critical evolution, cooperation as well as conflict management [Houtum, 2005]. This is a multi-disciplinary task and requires a good combination of geo-politic thinking, international relation theory, geographic analysis and geo-spatial information technology, as well as some other related subjects. New concepts, methods, algorithms, as well as advanced computing platforms need to be developed.

The paper aims to examine the major challenges of borderlands modelling and understanding in a digital age. Section Two gives a literature review of the state-of-the-art of in this field. The three major challenges in borderlands modelling and understanding are examined in Section Three. A research agenda is proposed in Section Four.

\section{LITERATURE REVIEW}

A GIS perspective is adopted to review the state-of-the-art of borderlands modelling and understanding in this section.

\subsection{Data sets development}

The early application of GIS in borderlands studies came from the field of international boundary making since the beginning of 1990s. GIS was found to be very useful for managing the voluminous boundary records [Adler, 2001]. A GIS-based digital boundary database was designed and developed to integrate all the multi-media, multi-temporal and multi-scale boundary documents and data since the middle of 1990s [Chen et.al., 2002] . By the end of 2010, China has completed its digital boundary with the length of over 22,000 kilometers [Chen et.al, 2012]. A boundary data model was also developed by the European Union to integrate both geometric and theme data of European nations.

The second type of borderlands data sets is focused on the adjacent administrative units from the neighboring nations. For instance, a dataset for United States-Mexico border regions was compiled, which comprises 25 U.S. counties in 4 states and 38 Mexican municipios in 6 states touching the two countries [Anderson \& Gerber, 2007]. As the political boundaries of counties and municipios are used for the geographical definition, the data are only limited to the census data from the decennial censuses of population and housing taken from 1950 to 2000 , along with estimates of a few variables for which there are no census reports (e.g., local income).

The third type of borderlands data sets developed has a global scale, but limited mainly to the digital representation of international systems. A typical work is CShapes, a data set on the historical maps of state boundaries and capitals in the post-World War II period [Weidmann et.al., 2010]. It has represented two different types of change of the shape and configuration of a state's core territory over time. One is the territorial changes occurring when states merge or dissolve, and the other is the change of the state configurations in the absence of emergence or disappearance of states. Although this kind of data sets is very important, other socio-economic and environmental information in border regions need to be collected.

As some important phenomena do not necessarily follow state boundaries, such as environmental influences, some efforts have been devoted to develop borderlands data sets along international rivers, cross-border zones, etc. Typical examples include the international river boundaries database [Donaldson, 2009], trans-boundary environments data [Parris, 2004], and cross-border disaster relief data [Lai, 2012].

\subsection{Theme spatial analysis}

The international boundary making has witnessed the GIS-based comprehensive spatial analysis. The demarcation of Iraq-Kuwait boundary and Israel- Jordan boundary is among the earlier applications [Adler, 2001]. Two special GIS_based boundary analysis systems were developed by National Geomatics Center of China through a combination of legal knowledge about international boundary and digital spatial analysis to support the international boundary delimitation and demarcation during the period from 1996 to 2010 [Chen et. al., 
The International Archives of the Photogrammetry, Remote Sensing and Spatial Information Sciences, Volume XL-4/W3, 2013 ISPRS/IGU/ICA Joint Workshop on Borderlands Modelling and Understanding for Global Sustainability 2013,

\section{5 - 6 December 2013, Beijing, China}

2012]. The first one was GIS-based boundary delimitation analysis system, aiming to bring the boundary in the real world on the negotiation table and to facilitate the difference settling and boundary delimitation on digital maps. The basic functionalities comprised the assembling, assessment and presentation of the evidence, difference analysis of disputed areas, preparation of attached maps and boundary treaty. It was an operational supporting system from 1996 to1999 during the China-Vietnam land boundary delimitation for the knowledge based decision making by diplomats, lawyers and political advisers. The second system was developed for supporting boundary demarcation by facilitating the transformation of the boundary defined on the map onto the digital landscape model and then to real terrain. The major functionalities consist of transforming analysis of boundary line, site selection of boundary markers, recording demarcation results and generation of attached treaty map. It had been used for supporting the entire demarcation process of China-Vietnam land boundary from 2002 to 2009 , as well as the inspection of the China-Nepal boundary.

Some boundary areas are characterized by extreme diversity in terms of geology, topology, demography, economy, as well as culture. Specific spatial analysis has been conducted to examine the unique phenomena. For instance, the nature of the contiguous borders that link enduring rivalry dyads was analyzed by modelling the ease of interaction and salience using GIS data [Starr, 2000]. Another example is the identification of the areas of high porosity or high permeability for pedestrians along the southern national border region in Carinthia, Austria using geo-computational analysis and terrain, land use, and road system data [Hisakawa et.al., 2013].

There has been an increase of theme analysis devoted to border regions during the past few years. For instance, trans-boundary water pollution analysis within two divergent cultural regions (western Washington and southern British Columbia) was conducted by using a newly developed Trans-boundary Environmental Management Index (TEMI) [Norman et.al. 2004]. Quantitative analysis was conducted for analyzing and understanding cross-border cooperation in the economic integration of the border regions European Union [Bergs, 2012; Sousa, 2012].

\subsection{Monitoring and management}

The border and the borderlands between the certain countries are very extensive and dynamic [Konrad and Nicol, 2011]. Earth observation can play an important role in borderlands monitoring and management. Airborne digital multispectral imagery and interactive image analysis techniques have been used to monitoring cross-border trails [Cao et. al. 2007]. The European and Commission (EC) and the European Space Agency (ESA) have launched a joint program, namely Global Monitoring for Environment and Security (GMES), to monitor the marine and land environment in an operational context [Donlon et.al., 2012]. It is designed to generate and deliver environmental information to decision makers by gathering and processing satellite, in situ and, socio-economic data. One of the GMES components is security service, which aims to provide intelligence and early warning services to support root-cause analysis of regional crises, such as weapons proliferation, fighting for natural resources, population pressure, land degradation, and illegal activities in the domains of migration and border monitoring natural resources and conflicts, nuclear and treaties monitoring and critical assets.

In addition, the collection of the situation information about boundary and borderlands was conducted by some institutions. For instance, the International Boundaries Research Unit, (IBRU) at the University of Durham has collected information on boundary events and territorial disputes around the world through a variety of international news and information sources [Donaldson and Pratt, 2005]. US and Canada agreed to work together, "not just at the border, but beyond the border to enhance the security and accelerate the legitimate flow of people, goods and services". Improving cooperative law enforcement capacity and national intelligence- and information-sharing are among the specific measures in implementing this "Beyond the Border action plan" [Vukov and Sheller ,2013].

\section{CHALLENGES IN BORDERLANDS MODELLING AND UNDERSTANDING}

Nowadays there is an awareness gap between borderlands challenges and UN SDGs. This can be mediated by advancing the borderlands studies through a new level of 
The International Archives of the Photogrammetry, Remote Sensing and Spatial Information Sciences, Volume XL-4/W3, 2013 ISPRS/IGU/ICA Joint Workshop on Borderlands Modelling and Understanding for Global Sustainability 2013,

\section{5 - 6 December 2013, Beijing, China}

research collaboration among the social natural, and engineering sciences. There are three major challenges in terms of borderlands modelling and understanding as illustrated by Fig.1.

\subsection{Integrated borderlands data modelling}

The representation of borderlands phenomena and events in a digital environment is one of the major tasks of borderland modelling. In comparison with the previously mentioned boundary data modelling, the abstraction and representation of borderlands features (objects) and their relationships take different ways. As the border regions are much larger than the boundary strip areas, a multi-scale and multi-resolution data modelling strategy is becoming necessary to meet different user requirements or priorities from their specific applications. In addition, some researchers need basic datasets of directly observed phenomena, while others prefer to utilizing derived forecasts product. It is therefore essential to understand the diverse and evolving range of user needs to identify critical borderlands features (objects). This will lead to the development of a borderland-specific spatial data model for the representation of the borderlands phenomena and events.

Due to the extensive and dynamic nature of borderlands, the formulation of borderlands models for analytical concerns is a difficult task. Brunet-Jailly (2005) had suggested a general framework of borders with four major components, i.e., market forces and trade flows, policy activities of multiple levels of governments on adjacent borders, the particular political clout of borderland communities, and the specific culture of borderland communities. This Canada-US-border based research result can provide us with some useful thoughts for the conceptual modelling of borderlands phenomena. However, the definition and representation of the key borderlands features (objects) and neighborhood variable needs more in-depth investigation.

The borderlands data collection and processing can be achieved through the utilization of earth observation, crowdsourcing information, conversion and harmonization of existing open data sets at global, regional and national scales. However, many existing social-economic and geo-political data often lack a clear spatial context referent, and the specific units and boundaries are often the same [Weidmann et.al., 2010]. The integration of all the available data sets for consistent and reliable borderlands data sets remains one of the most difficult tasks. New technical standards and data processing methods need to be investigated.

\subsection{Comprehensive borderlands analysis}

Cross-border co-operation and its win-win reciprocity depends significantly on a combination of various facilitating factors, including political leadership, economic competitiveness, cultural interaction, and geographical conditions [Megoran,2010; Sousa, 2012]. A better understanding of these border issues can be realized through historical trend analysis, operational tactical decision analysis, as well as strategic planning and forecasting. Currently, most borderlands analysis are single theme-oriented, such as economic integration of the border regions [Bergs, 2012; Sousa, 2012], cross-border cultural diversity and dynamism [Konrad and Nicol, 2011], trans-boundary environmental issues [Hannis et. al., 2013], combat against cross-border crime [Lo, 2009], and foreign diplomatic presence [Xierali and Liu, 2006]. A comprehensive analysis of the effects of geographical conditions and its synergy with social, economic, political and cultural analysis in borderlands affairs is still missing [Chen et.al., 2013; Lautze et.al. 2013]. The development of such comprehensive borderlands analysis is becoming another big challenge.

The geographical location and other geographical conditions have significant impacts or effects on the neighboring environment and borderlands policy. With advanced GIS-based spatial analysis, it is possible to compute their effects or evaluate the impacts, such as the differences of accessibility with or without geographical obstacles [Sousa, 2012], spatial interaction among various (political, economic, or cultural) neighboring units [Brambilla, 2008], spatial heterogeneity of landscape and neighborhood [Donaldson, 2008].There are a number of GIS spatial analysis methods available, such as multi-criteria decision analysis [Malczewski, 2006,], spatial relation computation [Chen et.al, 2001], etc., For instance, neighboring countries share common boundaries or have other kinds of adjacent relations. A Voronoi-based k-order relation model may be used for a quantitative and qualitative analysis modeled [Chen et.al., 2004].

Some borderlands phenomena and affairs require a synergetic analysis of both geographic condition and other 


\section{5 - 6 December 2013, Beijing, China}

socio-economic, cultural and environmental factors. For instance, international or regional emergency rescue and peace keeping activities is based on the geopolitical risk analysis and forecasting. The security and stability status, potential for cooperation and possible conflicts are among other subjects of synergetic analysis.

\subsection{Collaborative information service}

At present, most research institutions and organizations in the field of borderlands studies have kept their developed data sets for internal use for both historical and sensitive reasons. However, there are a few websites where some common data sets are published and can be downloaded, such as CShapes data set (http://nils.weidmann.ws/projects/cshapes), international river boundaries database (http://www.dur.ac.uk/ibru/ resources/irbd), U.S.-Mexico Border Dataset (http://latinamericanstudies.sdsu.edu/BorderData.html), Shared River Basin

Database

(SRBD,

http://www.prio.no/page/preview/preview/9244/45636.html), international freshwater treaties database (http://www.transboundarywaters.orst.edu/projects/ internationalDB.htm1). From the point view of web services, the data and services provided by these websites are fragmented in terms of coverage and are not connected, forming de facto "information islands". In addition, they provide only static or snapshot-based borderlands information. As border regions have a dynamic nature, a number of natural features or social-economic phenomena change over time, such as the changes in boundary watercourse bed, expansion of built up areas, economic growth, population increase, biodiversity degradation as well as territorial change. How to get historical and up-to-date borderlands data in an efficient way is becoming the third challenge in borderlands modelling and understanding.

A possible solution is to develop a web-based borderlands information portal through international collaboration. One of the tasks is to connect all the borderlands related open data sources scattered around the world and to provide 'one stop' information sharing and computing services. The other is to encourage continuous updating of the existing borderlands data. While earth observation approaches can be used for spatial change detection [Chen, 2013a], some other situation changes can be collected using topic-specific web crawlers from the huge source of information contained in the internet [Rungsawang and Angkawattanawit, 2005].

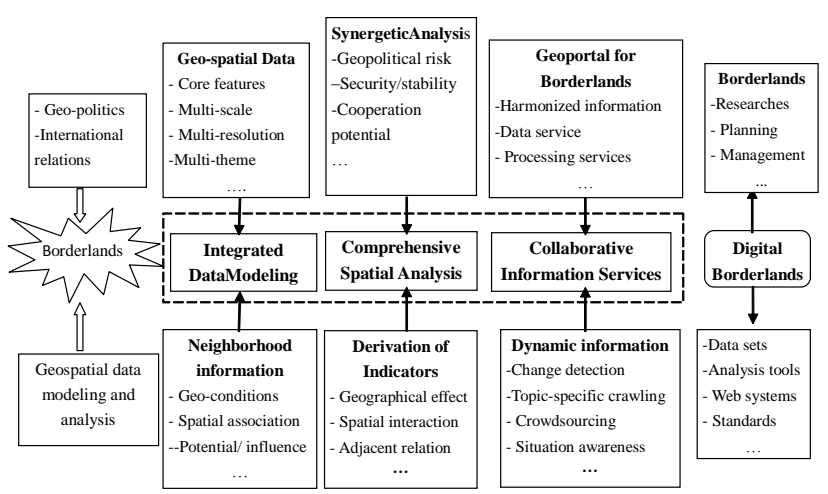

Figure 1 The framework of borderlands modelling and understanding

\section{A RESEARCH AGENDA}

In order to address to above challenges, a shift from previous 'digital boundary' to 'digital borderlands' is proposed with the advance of Earth Observation, GISs and Web technologies [Wang et.al., 2007; Zell, 2012]. The so-called ' digital borderlands' refers to a digital representation of borderlands phenomena and events, special borderlands analysis and simulation tools, as well as 'one stop' information portal [Chen et.al., 2013b]. It aims at providing more reliable information and more efficient tools to support borderlands studies, cross-boundary planning, development and management. Several theoretical and technological issues as below need further investigation:

\section{1) Classification and representation of borderland information}

Geo-spatial data and neighborhood information are two major kinds of data in 'digital borderlands' [Chen et.al., 2013b]. The former consists of multi-scale topographic data, multi-resolution imagery and land cover data, geographic names, as well as core borderlands features. The latter comprises geo-conditions, spatial association and geo-potential or influence. Their conceptual representation and logical data modelling all require sound formal classification and description of the core features (objects), relationships, operations and rules. 
The International Archives of the Photogrammetry, Remote Sensing and Spatial Information Sciences, Volume XL-4/W3, 2013 ISPRS/IGU/ICA Joint Workshop on Borderlands Modelling and Understanding for Global Sustainability 2013,

$$
\text { 5- } 6 \text { December 2013, Beijing, China }
$$

While topography, space imagery, land cover and land use, place names, administrative and other political units serve as the basic geo-spatial data, there are some core features (objects) and relations that are specific for borderlands studies. Some of these features (objects) are critical for a particular field, and others support a broad range of s borderlands studies. This gap can be filled by a cross-sectoral meta-analysis of borderlands study priorities from the perspective of users [Zell, 2012]. As far as the neighborhood information is concerned, a set of indicators spatial association need to be identified for representing integration in different domains, such as population migration, trans-boundary ethnics/religion/transportation for social association, bilateral trade, regional groups and FDI(I/O) for economic association, trans-boundary water, energy and minerals for resource association.

\section{2) Derivation of neighborhood information}

The derivation of neighborhood information raises some methodological and technical questions. Firstly, some neighborhood phenomena do not necessarily follow state boundaries, such as economic association and environmental influences. A well-designed multi-granular neighborhood tessellations as the basic spatial units will facilitate the collection, aggregation and processing of the indicators of the geo-conditions, spatial association and geo-potential or influences.

Secondly, special algorithms and approaches remain to be developed for deriving these indicators through the calculation or derivation of socio-economic statistics and other theme data.

\section{3) Development of synergetic analysis}

There are increasing demands for synergetic analysis of geopolitical risk, security and stability status, cooperation potentials for an entire neighborhood region, a specific transportation life line, or some other specific areas. Domain-specific analysis models should be developed, including the definition of appropriate evaluation criteria and models, comparison of alternative actions and the formulation of policy advices. This will depend on the understanding of the borderlands phenomena or affair concerned and can be supported by a good combination of geopolitical thinking, international relation analysis and GIS-based geo-computation.

\section{4) Design and development of a geo-portal for borderlands studies}

The harmonised borderlands information and collaborative information service can be embedded through the design and development of a geoportal, which is a special type of web portal, dealing with geospatial data and geospatial processing services [Longueville, 2010; McInerney et.al., 2012]. This geoportal will not only serve as a data dissemination platform, but also as an open system that supports the discovery, exchange, advertisement and delivery of borderlands information resources on the Web [Chen et.al, 2013a;2013b]. Highest level of semantic interoperability, crowdsourcing information collection, topic-specific web crawling, change monitoring with multi-temporal imagery, ontology-based online situation awareness is among the key issues to be investigated.

\section{CONCLUSIONS}

Border regions are very important areas in our changing world and deserve more attention in the global sustainable development. A clearer awareness and well-coordinated development of the border regions will reinforce the UN SDGs and benefit the human beings. This can be advanced by promoting borderlands modelling and understanding with new modelling and analysis capabilities. This paper identified integrated data modelling, comprehensive analysis and collaborative information service as the three major challenges in this filed from a GIS perspective. A research agenda was further proposed with four major topics, i.e., classification and representation of borderland information, derivation of neighborhood information, development of synergetic analysis, and design and development of a geo-portal for borderlands studies.

Borderlands modelling and understanding is an interdisciplinary study. A new level of research collaboration among the social, natural and engineering sciences is requested to develop innovative concept, methods, algorithms, as well as advanced computing platforms. In particular, a closer and in-depth collaboration of geo-politics, international relation, geography and geo-spatial information sciences is obligatory. 
The International Archives of the Photogrammetry, Remote Sensing and Spatial Information Sciences, Volume XL-4/W3, 2013 ISPRS/IGU/ICA Joint Workshop on Borderlands Modelling and Understanding for Global Sustainability 2013, 5 - 6 December 2013, Beijing, China

\section{References}

Adler, R., 2001. Geographical Information in the Delimitation, Demarcation and Management of International Land Boundaries. IBRU Boundary and Territory Briefing, 3(3), ISBN 1-897643-40-3 2000.

Anderson, J. B., \& Gerber, J. 2007. A dataset for U.S. - Mexico border research. Journal of Borderlands Studies, 22(2), pp.113-118.

Anderson, M., 1996. Frontiers - Territory and State Formation in the Modern World. Polity Press.

Bartelmus, P., 2013. The future we want: Green growth or sustainable development? Environmental Development 7, pp. $165-170$.

Bergs, R., 2012. Cross-border Cooperation, Regional Disparities and Integration of Markets in the EU. Journal of Borderlands Studies, 27(3), pp.345-363.

Bernal, J. M \& Sols, A. H., 2000. Conflict and Cooperation on International Rivers: The Case of the Colorado River on the US - Mexico Border. International Journal of Water Resources Development, 16(4), pp.651-660.

Brambilla, C., 2008. New approach in border studies: The need for re - thinking the European - African borderland through the case of the EUSADC relationship and the caprivi strip. Journal of Borderlands Studies, 23(3), pp.55-68.

Brunet-Jailly, E., 2005. Theorizing Borders: An Interdisciplinary Perspective. Geopolitics, 10(4), pp. 633-649. Brunet-Jailly, E., 2011. Special Section: Borders, Borderlands and Theory: An Introduction. Geopolitics, 16(1), pp.1-6.

Cao, L., Stow, D., Kaiser, J., \& Coulter, L., 2007. Monitoring cross-border trails using airborne digital multispectral imagery and interactive image analysis techniques, Geocarto International, 22(2), pp.107-125.

Chen, J., Li, C-M., Li, Z-L., \& Gold, C. M., 2001. A Voronoi-based 9-intersection model for spatial relations, Int. J. of GIS, 15(3), pp. 201-220.

Chen, J., Zhao, R-L., Li, Z-L., 2004. Voronoi-based K-order neighbour relations for spatial analysis. ISPRS Journal of Photogrammetry and Remote Sensing, 59(1-2), pp.60-72.

Chen, J., Li, J., He, J. \& Li, Z-L., 2002. Development of Geographic Information Systems (GIS) in China: An Overview. Photogrammetric Engineering and Remote Sensing, 68(4), pp.325- 332.

Chen, J., Hua, Y-X., Wang, F-L., Chen, H-B, Liu, W-Z, Zhou,
Z-W., \& Zhang, Y. 2012, Research and establishment of China's Digital Boundary, ACTA GEIDEICA et CARTOGRAOHICA SINICA, 41(6), pp.791-796 (in Chinese). Chen, J-M., Lu, X-H., Chen, J., Chen, L-J., \& Chen, J., 2013a. A Spectral Gradient Difference Based Approach for Land Cover Change Detection. ISPRS Journal of Photogrammetry and Remote Sensing, 85, pp.1-12.

Chen, J., Ge, Y-J., Hua, Y-X., Wang, F-L., Yang, S-T., Qu, B., Li, R. 2013b. Digital Borderlands: Conceptual Framework and Research Agenda. Bulletin of Surveying and Mapping, 2, pp.1-4 (in Chinese).

Chen, J., W, H., Li, S-N., Liao, A-P., He, C-Y., \& Cheng, D-Y. 2013c. Temporal Logic and Operation Relations Based Knowledge Representation for Land Cover Change Web Service. ISPRS Journal of Photogrammetry and Remote Sensing, 83, pp. 140-150.

Chen, J., Wu, H., Li, S-N., Chen, F., \& Han, G., 2013d, Service oriented dynamic computing for land cover big data, Journal of Geomatics Science and Technology, 30(4), pp. 369-374 (in Chinese).

Donaldson, J. W., \& Pratt, M., 2005. Boundary and Territorial Trends in 2004. Geopolitics, 10(2), pp.398-427.

Donaldson, J. W., 2008. Politics and scale in boundary-making: the work of boundary commissions. Journal of Historical Geography, 34, pp. 393-396.

Donaldson, J. W., 2009. Where rivers and boundaries meet: building the international river boundaries database. Water Policy, 11, pp. 629-644.

Donlon, C., Berruti, B., Buongiorno, A., Ferreira, M-H., Féménias, P., Frerick, J., Goryl, P., Klein, U., Laur, H., Mavrocordatos, C., Nieke, J., Rebhan, H., Seitz, B., Stroede, J. Sciarra, R., 2012. The Global Monitoring for Environment and Security (GMES) Sentinel-3 mission. Remote Sensing of Environment 120, pp. 37-57.

Hecht, A.D., J. Fiksel, S. Fulton, T. Yosie, N. Hawkins, H. Leuenberger, J. Golden, \& T. Lovejoy, 2012,

Creating the future we want, Sustainability: Science, Practice, \& Policy, 8(2):62-75.

Hannis, S., Bricker, S., Goater, A., Holloway, S., Rushton, J., Williams, G., \& Williams, J., 2013. Cross-international boundary effects of $\mathrm{CO} 2$ injection. Energy Procedia, 37 , pp. $4927-4936$.

Hisakawa, N., Jankowski, P., \& Paulus, G., 2013. Mapping the porosity of international border to pedestrian traffic: a comparative data classification approach to a study of the 
The International Archives of the Photogrammetry, Remote Sensing and Spatial Information Sciences, Volume XL-4/W3, 2013 ISPRS/IGU/ICA Joint Workshop on Borderlands Modelling and Understanding for Global Sustainability 2013,

\section{5 - 6 December 2013, Beijing, China}

border region in Austria, Italy, and Slovenia. Cartography and Geographic Information Science, 40(1), pp. 18-27.

Houtum, H.V., 2005. The Geopolitics of borders and boundaries. Geopolitics, 10, pp.672-679.

Konrad, V. \& Nicol, H., N., 2011. Border Culture, the Boundary Between Canada and the United States of America, and the Advancement of Borderlands Theory. Geopolitics, 16(1), pp.70-90.

IGU, The International Year of Global Understanding (IYGU)an initiative of The International Geographical Union (IGU), www.global-understanding.info (31 Oct. 2013).

Iwashita, A., 2008. Border dynamics in Eurasia: Sino - soviet border disputes and the aftermath. Journal of Borderlands Studies, 23(3), pp.69-81.

Lai, A. Y-H., 2012. Towards a Collaborative Cross-border Disaster Management: A Comparative Analysis of Voluntary Organizations. Journal of Comparative Policy Analysis: Research and Practice, 14(3), pp.217-233.

Lautze, J., Wegerich, K., Kazbekov, J. Yakubov, 2013. International river basin organizations: variation, options and insights. Water International, 38(1), pp.30-42.

Lo, S., 2009. Globalization, State Autonomy and the Fight against Cross-Border Crime: Greater China's Cooperation with the World. Asian Journal of Political Science, 17(3), pp.299-322.

Longueville, B. D., 2010. Community-based geoportals: The next generation? Concepts and methods for the geospatial Web 2.0, Computers, Environment and Urban Systems, 34, pp. 299-308.

Malczewski, J., 2006. GIS - based multicriteria decision analysis-a survey of the literature. International Journal of Geographical Information Science, 20(7), pp.703-726.

McInerney, D., Bastin, L., Díaz, L., Figueiredo, C., Barredo, J. I., \& Ayanz, J. S-M., 2012. Developing a Forest Data Portal to Support Multi-Scale Decision Making. IEEE Journal of Selected Topics in Applied Earth Observations and Remote Sensing, 5(6).

Megoran, N., (2010). Neoclassical geopolitics. Political Geography, 29, pp.187-189.

Norman, E. S. \& Melious, J. O., 2004. Transboundary environmental management: A study of the Abbotsford - Sumas aquifer in British Columbia and western Washington, Journal of Borderlands Studies, 19(2), pp.101-119.

Parris, T. M., 2004. Managing Transboundary Environments.
Environment: Science and Policy for Sustainable Development, 46(1), pp.3-4.

Pereira, H. M., \& Ferrier, S., et.al., 2013, Essential Biodiversity Variables, SCIENCE, 339(18), pp.277-278.

Rungsawang, A. \& Angkawattanawit, N., 2005. Learnable topic-specific web crawler. Journal of Network and Computer Applications 28, pp.97-114.

Sousa, L. D., 2012. Understanding European Crossborder Cooperation: A Framework for Analysis. Journal of European Integration, DOI: 10.1080/07036337.2012.711827

Starr, H., 2000. Using geographic information systems to revisit enduring rivalries: The case of Israel. Geopolitics, 5(1), pp. 37-56.

United Nations, 2012. The Future We Want,. http://www.uncsd2012.org/content/documents/

727The\%20Future\%20We\%20Want\%2019\%20June\%201230p m.pdf (31 Oct. 2013).

Carpenter, J. and J. Snell, 2013. Future Trends in Geospatial Information Management: The Five to Ten Year Vision, Ordnance Survey, ISBN: 978-0-319-08792-3

Vukov, T., \& Sheller, M., 2013. Border work: surveillant assemblages, virtual fences, and tactical counter-media. Social Semiotics, 23(2), pp. 225-241.

Wang, F-Y., Zeng, D., Carley, K. M., Mao, W-J., 2007. Computing-From Social Informatics to Social Intelligence, IEEE Intelligent Systems, pp.79-83.

Weidmann, N. B., Kuse, D., \& Gleditsch, K. S., 2010. The Geography of the International System: The CShapes Dataset, International Interactions: Empirical and Theoretical Research in International Relations, 36(1), pp. 86-106.

Xierali, I. M. \& Liu, L., 2006. The Effect of Power and Space on Foreign Diplomatic Presence in the United States: a Spatial Modelling Approach. Annals of GIS, 12(2), pp.53-63.

Zell, E. A. K. H., Carpenter, A. T., \& Friedl, L. A., 2012. A User-Driven Approach to Determining Critical Earth Observation Priorities for Societal Benefit. IEEE Journal of Selected Topics in Applied Earth Observations and Remote Sensing, 5(6), pp.1594-1602 